\author{
LUKASZ DONAJ, \\ Adam Mickiewicz University in Poznań (Poznań, Poland) \\ e-mail: lukasz.donaj@amu.edu.pl, ORCID 0000-0002-7720-1260 \\ VITALIY ZAVADSKYI, \\ Borys Grinchenko Kyiv Uviversity (Kyiv, Ukraine) \\ e-mail:v.zavadskyi@kubg.edu.ua, ORCID 0000-0002-0384-5979
}

\title{
POLISH WAY TO THE INFORMATION SOCIETY
}

\begin{abstract}
The article is devoted to a wide range of issues connected with the social and cultural changes that accompany the transition from industrial to information society. The aim of the issue is to demonstrate the Polish way to information civilization. Regarding this goal the author used the following methods: historical, behavior (indirect) analysis, decision making method as well as extrapolation and reflection. The issues of concepts' specificity connected with the information society are discussed in the article. The specific nature of Polish society transformation in the context of external factors regarding European integration and global social processes in general is analyzed. The historical dynamic of Polish information infrastructure establishment has been presented; the way has been indicated as incomplete consequently the information transformations have not been completely accomplished in Poland.
\end{abstract}

Key words: information society; Poland; transformations; Lisbon Strategy; European Strategy 2020.

\section{Introduction}

The processes of social change and social development in the most developed countries are versatility discussed in the works of various authors. As the sociologist A. Niesporek mentioned new forms of social life were called "information society", "postindustrial society", "post capitalist society", "post marketing society", "post civilizational epoch", "period of reflexive modernization", "third-wave society", "risk-taking society", "networked society", "technological or knowledge society", and eventually "capitalism-consuming" society (Niesporek, 2018). The term "information society" is considered in the light of presenting such type of society which is characterized by the high level of information technologies distribution, namely the means of gathering, transmitting, processing and storing information. The information society was a consequence of the third civilizational revolution (IT-revolution) that occurred in the second half of the $20^{\text {th }}$ century. A source of economic growth of the information society is production and information distribution which is a product accepted into market trade. For the first time the term "information society" was implemented in Japan in 1936, later it was popularized by Yu. Masuda in 1972. The concept "information society" was spread by S. Nora and A. Mink in Europe in 1978. The development of information society is supposed to be the main source of the global processes (Pawł owska, 2005: 372).

Traditionally, it is not the only definition of the term; particularly the phenomenon has still been ambiguous.

The philosopher A. Kocikowski reminds the words of the Polish civil activist and software engineer M. Nowak: "A new type of social body could be noticed at the second half of the $20^{\text {th }}$ century that was widely known as "information society". The distinctive feature is the rapid growth of the information communication technologies (ICT). Nevertheless, what is the base for this statement? Who has claimed that? Could we observe the emergence or establishment of a new social type? And going further, we are asking what does the term "social body" mean? Is it a new "way of production" due to M. Karol? Or can it be a new type of society, for instance, "non-capitalistic society" or something beyond capitalism that is understood as a precisely defined "network of social relations", however, what is exactly? Or may it be specific national or supranational corporation which is organized and acts differently in comparison with classical corporation in the sphere of capitalistic economy?" (Kocikowski, 2009: 3-4).

A. Kocikowski considers ambiguity in the mentioned notes and is not able to define whether "a new type of social body" has a systematic character, consequently it refers to the modern capitalistic society as the whole. The discussed form "social art" emerges in every group which uses the various ways of capital accumulation aimed at the favorable conditions' establishment for personal life recreation, or we meet it in the particular capitalistic societies, for instance, only Northern American (the USA) or German (Finnish or French). Might a supranational community emerge for which a "traditional" form (namely national within the territorial and identical dimensions) is not necessary for achieving connections determined the term "society"? May "a new type of social body" be established within the particular borders of one type society (capitalistic society), in the middle of all societies of that type (capitalistic society), beyond the structure of all societies of the same type (capitalistic society), still with the significant individual participation? (Kocikowski, 2009: 4). If we agree with M. Nowak that the main peculiarity of "a new type of social body" is represented by "the rapid growth of ICT", the question will arise as to whether this "rapid growth of ICT" is the unique peculiarity of "a new type of social body" emergence or it is one of the numeral components, albeit the most crucial one. We need to return to the issue whether a rapid growth of any technology (namely undefined one) can lead to the emergence of "a new type of social body" or is it only ICT's peculiarity? It is the most essential issue as the vast majority of biologists and 
physics easily present the serious arguments for a thesis that the development of bio and nanotechnologies occurred during the last years (in our case the last decade) has surpassed its dynamic compared to ICT's development during the relevant period of their history. If the thesis was convincingly justified, would it support the fact that "a type of social body" had been created before our eyes? (Kocikowski, 2009: 3-4).

An attributive side of the new social body should be new established values. Meanwhile, we are inclined to agree with the Ukrainian researchers O.P. Dzeban, O.S. Aleksandrova and N.M. Vinnikova that we are in the pre-values situation where "the incredible variety of personal experience which is obtained via multiplicity and simultaneity of virtual practices in different spheres of life (simulaclarization) and may mistakenly be accepted as try personal experience" (Dzeban, Aleksandrova, Vinnikova, 2019: 17).

Moreover they warn that a person has not been emotionally and intellectually ready for freedom yet, for such kind of freedom created by expanded reality of information space, as the algorithms of structuring and critical information consideration has still been established and are partially correlated with the available axiological complexes (Ibid).

Modern information society is consisted of a computer and the Internet supplemented by various other mass media according to the sociologist M. Golka. The human mass media stores information to some extend and more traditional ways of communication are used. All these methods have different efficiency of communication, perform various functions and are applied to different circumstances. While considering information society all the diversity can be ignored, just remember that all of them are intertwined with a cybernetic knot and the opportunities of digital communication determine the specific features of modernity as well as they influence on the old means of communication, namely on a way of writing and speaking (Golka, 2005: 257). Therefore, information society has a lot of peculiarities from traditional societies as well as a lot of new functions. Practically, functioning of information society is consisted of the following parts determined by M. Golka:

- e-mail usage;

- information usage posted online on the websites and in databases;

- purchases and auctions;

- the emergence of professional events that are broadcast at home via the Internet in lieu of the working place (so called telework or cyber-company);

- banking usage;

- legal and medical services usage;

- Internet learning possibilities, e-education;

- Internet religious presence;

- Internet political activities;

- contacts with the government authorities;

- social life, acquaintances and even marriages contracted via the Internet;

- press review;

- lessons, literature and art circulation;

- museum resources usage;

- library resources usage;

- in addition cybercrime, pornography, terrorism and even begging (Golka, 2005: 260).

Consequently M. Golka has drawn a conclusion that the information society has covered almost all aspects and spheres of life, the presented collection has gradually become total, nobody can get rid of it, live without it and underestimate it. Furthermore, it is absolutely new type of behavior in comparison with the past or even a new way of life. Thus, it proves Makluchan's crucial thesis about "a relay race which is a message" that simultaneously creates the new environment for human functioning (Golka, 2005: 260).

\section{Results and Discussion}

Polish Way for Information Society (with the EU in the Background).

With regard from the common philosophical issues to Polish way and the information society, we need to mention the way of Polish social and political transformation which has still continued. The sociologist M. Nowak presented five periods of Polish changes:

1) "honeymoon of transformation" (1989-1991);

2) "meticulous everyday transformation" (1991-1999);

3) "turbulent end of transformation" (1999-2002);

4) "double inviolability" (2002-2003);

5) Poland accession to the EU structures (2003-2008) (Nowak, 2010: 176-184).

The media expert R. Filas, who has already analyzed the mass media development, analyzes the end of the $20^{\text {th }}$ century (1989-2000). He determines four sub periods ("phases") in this "relatively developed decade":

1) a phase of live enthusiasm of the editors and linguists as well as a forced transformation of the old names (lasts from May 1989 to the middle of 1991);

2) a phase of obvious stabilization and "hidden changes" in press and radio (lasts from the middle of 1991 to the end of 1992);

3) a phase of open struggle for media market, especially audio and visual one (lasts from the beginning of 1993 to August 1994);

4) a phase of new market division and progressed specialization (1997-2000) (Filas, 2010: 30).

R. Filas divided all next years according to the following stages:

5 ) a stage of increasing domination of Internet mass media in crisis situations (2001-2003);

6 ) a stage of previous reconstructions of the traditional mass media products under the circumstances of expected invasion of new media technologies (2004-2007);

7) a stage of real confrontation between the traditional mass media and new media technologies under the conditions of economic slowdown (2008 - till nowadays) (Filas, 2010: 37).

It should be mentioned that Poland accession to the European Union is generally a crucial turning point. Poland became a member of the European Union from the first of May 2004 under the Treaty of Accession ratified in Athens on April $16^{\text {th }} 2003$ and it was a legal base for Poland accession to the European Union. During the negotiations an issue about accession to the information society in general was discussed in the chapter 19 devoted to the issues of telecommunications and information technologies. Generally, the term "information society" has horizontal dimension and is indirectly presented in all areas. The concept of "information society" in the European Union is the specific core, key to modernity, knowledge-based economy, strong common market, global competitiveness and active unemployment prevention (Marciński). The EU policy foundation in the sphere of information society's establishment was formulated in the White Papers issued by European Commission in December 1993 entitled "The Growth, Competitiveness, Employment - the Challenges and Ways forward into the $21^{\text {st }}$ century". European Com- 
mission considered the issues and the scale of challenges and opportunities for Europe in the White Paper for the first time that brought the new information and communication technologies and admitted the significant influence of the information and communication technologies (ICT) on sustainable growth and employment promotion. The year 1994 was an actual beginning of information society when the former EU commissioner M. Bangman, responsible for telecommunications and information technologies development, issued a document "Europe and the Global Information Society". The recommendations to the European Council were known as Bangman's Report where the comments about changes fueled by modern information and communication technologies were presented. The European Commission issued the Green Paper "Living and Working in the Information Society: People first" in July 1996. The document is oriented on the consequences for the civils that can emerge in a way of transformation to the information society and influence of ICT on human life is considered.

The manifest for common policy about modern and strong economy establishment for all countries-members the EU was the initiative "eEurope - An Information Society for All" declared at the summit in Helsinki in December 1999. The ultimate goal of all changes was to create a new type of society, applying the possibilities of new economy and regarding the priority directions such as education, transport, healthcare sphere and professional employment of the disabled. The common access to the Internet became a priority goal of the European Union policy.

The new political and economic strategy of the EU was launched at the meeting of the European Council in Lisbon under the name the Lisbon Strategy during March 23-24 th 2000. It was implicit that the EU would reach the dominant economic position in the world till 2010 and secure all the EU citizens employment and high social standards. It contained European conception about the information society creation that would meet the goals of modern knowledge-based economy and economic cohesion.

Regarding to the program eEurope, two action plans were presented for the Lisbon Strategy realization by the European Commission: during 2000-2002 and 20032005. The action plan "eEurope 2002 - An Information Society for All" was presented at the summit in Feira in 2000 and was completely devoted to the political agenda in the Internet. It pointed to the necessity of high-speed, cheap and safe Internet, investment into the computer skills of European users and online apps stimulation. The action plan "eEurope 2005: An Information Society for All" was presented at the summit in Seville in June 2002. It was oriented on the political activity aimed at wide access organization for the Europeans and European companies to the new age of information and communication technologies (broadband network, mobile phones of the third generation and digital television), favorable environment creation for the private investment, new professions and working places creation, state service modernization (egovernment, e-learning, e-healthcare, e-business). Then countries-candidates for the EU also joined to eEurope initiative.

During the conference of European Ministers in Warsaw the agreements were reached about a plan creation similar to eEurope in May 2000. Getebourg presented the plan "eEurope + 2003: A Cooperative Effort to Implement the Information Society in Europe" in June 2001. The action plan supposed the acceleration of the integrity processes and regulatory market liberalization of information and communication, national plans realization regarding computerization. The crucial step in the way of the information society establishment was implementation of the document "Working Together for Growth and Jobs. A New Start for the Lisbon Strategy" called the renewed Lisbon Strategy at the European Council summit in March 2005. The decision about the Lisbon Strategy revision was accepted when the goals were revealed to be unattainable till 2010. The renewed Lisbon Strategy stressed innovations and knowledge-based economy establishment as well as improved business conditions. The strategy included the following priorities: 1) knowledge and technological innovations transformations into the real force of the permanent growth in Europe; 2) enhancing European attractiveness in the sphere of investment and employment; 3 ) economic growth and employment submission to the social community, the total synergy support between economic, social and ecological components. The priorities were included into the strategic recommendations of the Union for 2007-2013. The first initiative of the new Lisbon Strategy was the initiative "i2010 - A European Information Society for Growth and Employment" was accepted by the European Commission in June 2005 (Rozwój Społ eczeństwa; Strategia Lizbońska).

According to the Lisbon Strategy, the strategical goal of the EU development was to become the most competitive and innovational economy in the world till 2010. Within the Lisbon Strategy and initiative eEurope, a lot of political actions aimed at information society establishment through trade, governmental, healthcare, education etechnologies usage were performed. One more document - the Strategy-2020 that was oriented on economic growth after the period of global crisis 2008-2010 was accepted in 2010. The document was supposed to be precise and global (Demczuk, 2016: 25; Strategia Europa 2020). According to the lawyer and political scientist A. Demczuk the Lisbon Strategy has often been critically evaluated (especially by the mass media), however its meaning and particular innovative way of thinking regarding the creation of information society's policy cannot be crossed. Although the consequences of the Lisbon reforms were distributed due to the country, region and type of information service, "The Lisbon Policy" determined a way of European policy in general and implied the accepted decisions regarding the necessity of close cooperation in the horizontal dimension for the technological infrastructure development as well as for non-formal education support with ICT usage. It made transparent for the authorities at the national level that only common and coordinated policy at the supranational level had a chance to act successfully and achieve goals of innovative knowledge-based e-economy development. The strategy "Europe-2020" is considerably based on the Lisbon Strategy and is its continuation. It is specifically vivid in the spheres of quantitative goals. The EU policy of development presented in the new strategy forward into the $21^{\text {st }}$ century is to concentrate on the recession and its consequences overcoming, moreover on the EU economy transformation into more ecologic, innovative with the high level of employment and social cohesion. The document includes the new definition of the EU development model as "permanent social market economy" that concerns economic development which should secure economic progress and universal opportunity for sustainable development and better life that lies at the core of the new European strategy. The Lisbon Strategy was numerously changed during implementation regarding the scope as well as the way of realization. 
The same case is with the strategy "Europe-2020". It should be mentioned that the main problem of the $E U$ is its low competitiveness in the global economy regarding the high living standards of the citizens. Asian countries have rapidly developed as well as they are influential. The financial crisis in Greece became a huge problem where any attempts to restore financial balance met tough social opposition. Disintegrational tendencies can be an additional problem for the new strategy in the aims' achievement, for instance it has led to Brexit fail (Demczuk, 2016: 41-42).

Nowadays Poland has experienced two major transformations - adaptation to the European Union demands in order to integrate with it and transformation into the global information society. Public opinion more or less is informed about the first transformation; the further changes are considered to be temporally remoted and are not qualified as the main problems of Poland. The truth is rather different; integration with the European Union in reality is rather chasing delay of becoming a part of Europe appeared after the Second World War, simultaneously transformation into a global information society is the challenge with which the most developed part of the world has lived. Poland's participation into this transformation is a struggle for Poland's place and the destiny of the Polish in the future (Cellary).

A global information society will be distinguished from our present society as our society fundamentally differs from an agrarian society represented by the enslaved peasants, that was a bit more than a hundred years ago which is a slight length of time for human civilization. A transformation mechanism into a global information society is the following. The scientific and technological progress in the sphere of information technologies and telecommunications despite a source of its inspiration leads to the new business decisions implemented into economy. The industrial changes evoke the range of changes in forms, means, methods and work organization. The working style modification along with the proposition of new products and services influences on life style modification. Simultaneously the new technical possibilities, economic changes and life style modifications have an impact on social organization and all the social institutes. Culture and education become the key elements of participation in a global information society. Culture is involved into the process more than ever, on the one hand it becomes a product on the market and a condition of economic success, and on the other hand it plays a special role in the process of national identity support under the circumstances of globalization. Furthermore, education reveals its affiliation to a global information society in the form of life-long learning for all citizens and not only for the young, which is a sign and peculiarity of information society's development (Cellary, 2002).

The old but existing Report about social development entitled "Poland and the Global Information Society" (2001) prepared by the program of UN development (UNDP) in Poland should be mentioned. The report analyzed the current state of Poland, shows a future perspective in five extensive interconnected fields: economy, work, society, culture and education. The report inspires to consider a global information society and Poland's place in it. We are aware of total saturation with information and telecommunication technologies; nevertheless what is a human role in the upcoming world? What are the working demands for a human? What will be crucial for human development? What will be a social structure and institutes?
What will be the intrinsic peculiarities of e-economy? What place will find culture in economy and society under the globalization circumstances? How education should be organized in the light of constant human learning in order to keep pace with the development (Cellary; Raport o Rozwoju).

The authors of the report indicate that the following positions are vital for Poland's positive commitment to the path leading to the global information society:

- new economic policy oriented on Polish economy transformation according to the principles of knowledgebased e-economy and integration of Polish economy into the global economy;

- new policy for IT, telecommunications and the mass media (electronic and ordinary media) through the long process of convergence and their meaning for future development;

- new working policy that should take into account the new forms of work support and innovative work organization;

- new scientific policy for Polish science facilitating the highest transformation of Polish society into a global information society which demands close connections with Polish economy;

- new cultural policy that provides an opportunity to offer Polish culture in the form of digital products on a global market and secures its longevity and development in Polish society;

- adaptation of public administration for the new challenges at all levels, in order to eliminate administrative brake for social and economic development;

- far-reaching legal changes that should be adapted to the electronic economy and a global information society's demands as well as to the previous studies including international ones regarding the legal decisions;

- deep changes in the education policy as the Ministry of Education engaged in the current reform of school education should not underestimate the responsibility for people training for a global information society. The essential role refers to the Ministry of Labor and Social Affairs here that should determine the requirements for education system as the efficiency in a struggle with unemployment vastly depends on the education quality of "working people". State education policy should include development of the various forms, namely the whole system of life-long learning adult education should support their knowledge level and competencies, secure their competitiveness on the fast-changing labor market (Cellary, 2002; Raport o Rozwoju, 2001).

Whether the above enumerated tasks have been realized from the moment of Poland's accession to the EU structure? Generally, an answer is not really optimistic, however considerable progress can be noticed compared to the recent years. Applying to the Central Statistical Office, the progress can be noticed despite the fact that it can consistently be better.

In $201983.1 \%$ households used one computer, consequently at least one person at the age of 16-74 years. The proportion has steadily increased each year, in contrast to the previous year the rate has grown by 0.4 percentage points.

In $201986.7 \%$ households had access to the Internet that had 2.5 percentages increase compared to the previous year. The proportion of households that use the Internet via a broadband Internet connection has soared a further 4 percent. The Internet accesses as well as a type of Internet connection depended on a household type, 
standards of living and a level of urbanization. The households with children have more Internet access than without them. Regarding the households' location, a percentage of households with the Internet was higher in cities than in country, and according to the level of urbanization the highest percentage of Internet usage was in the highly urbanized regions. The same pattern is similar to the usage of broadband Internet access.

In 2019 the common reason of absence of the Internet at home, as in the previous years, was the lack of usage necessity. The second crucial reason was the lack of appropriate skills. The high price of equipment and Internet access is the reason that has becoming rare each year.

In 2019 the persons who had used online state services for the last 12 months were $40 \%$ of the population at the age of 16-74 years. The group of people who use the option for online forms filling and returning the filled forms has increased each year. In 2019 a percentage of people who downloaded online forms had yearly inclined by 2.5 percentage points, and those who sent by 6.8 percentage points.

In $201953.9 \%$ of people at the age $16-74$ performed online shopping in Poland. The huge disproportions can be seen in the respondents' place of living, the discrepancy between urban and rural inhabitants was 9.7 percentage points.

In $201917.5 \%$ companies used the chargeable cloud service that was a 6 percent increase compared to 2018 . Among the services proposed in cloud calculations the most popular were e-mail services - $12.9 \%$ companies used it (that was a 5.2 percent increase compared to the last year).

In $201815.7 \%$ companies got orders for products in eform, $11.3 \%$ performed sales via corporate website or mobile app, $6.4 \%$ via online external sales platforms and $4.3 \%$ via EDI (Electronic Data Interchange).

In $201816.9 \%$ of the companies used open publicly available data (data of organizations and offices provided to stakeholders for usage and processing with any aim), the highest interest was paid to the public data in economic and financial issues $(15.1 \%)$

The companies needed to take various measures for ICT-infrastructure protection against numerous threats elimination that could occur in a network. In 2019 the most frequent secure measures were regular programs updating and powerful passwords authentication $(80.8 \%$ and $76.4 \%$ respectively). Among the problems that occurred due to the ICT security violation were generally inability to use ICT resources, for instance, owing to the DoS attacks, blackmail programs, and also elimination or data corruption, for instance due to infection of malicious software ( $8.6 \%$ and $7.9 \%$ respectively).

The robots were much more frequently used in the different economic spheres. In 20197.5 companies used robots in their operations, including $5.7 \%$ industrial robots, $2.9 \%$ service robots. The highest percent of companies which used robots were among the big households $28.4 \%$. The attention of the companies was focused on the industrial robots $(25.3 \%)$ and less frequently on service robots $(8.1 \%)$ (GUS, 2019).

\section{Conclusions}

The modern world demands the usage of high quantity of information. As W. Krztoń from Rzeszów University of Technology highlights people are involved in various social, political, economic processes, consequently they have drowned in the information. A state or society without a precise information sphere is not able to function effectively. The Internet explosion has changed everything: human relations, the way of policy, work and success achievement. Only a person who has been briefed can make right decisions. Information is the same treasure as natural wealth, namely coal, oil or gas. A society of the $21^{\text {st }}$ century is the society of rapid information circulation.

Consequently, the $21^{\text {st }}$ century is based on information and on its process, retain and transmission. Are we ready for the opportunities that have been revealing before us as humans by the information civilization and the threats that accompany them? Can we claim that information society has completely established?

The answer to the question has remained open.

\section{REFERENCES}

Cellary, W. (ed.) (2002). Streszczenie raportu o Rozwoju Społ ecznym Programu Narodów Zjednoczonych ds. Rozwoju. (In Polish)

Demczuk, A. (2016). Od raportu Bangemanna do Strategii Europa 2020. Rozwój społeczeństwa informacyjnego w polityce Unii Europejskiej - bilans 15 lat. Annales Universitatis Mariae CurieSkłodowska, vol. XXIII, 2 sectio k: 25-44. (In Polish)

Dzeban, O., Aleksandrova, O., \& Vinnikova, N. (2019). Axiological portrait of information society. Skhid, 5(163), 13-19. DOI: http://dx.doi.org/10.21847/1728-9343.2019.5(163).18243

Filas, R. (2010). Dwadzieścia lat przemian polskich mediów (1989-2009) w ujęciu periodycznym. Zeszyty Prasoznawcze, 34: 27-54. (In Polish)

Golka, M. (2005). Czym jest społeczeństwo informacyjne? Ruch Prawniczy, Ekonomiczny i Socjologiczny, 4: 253-265. (In Polish)

GUS (2019). Społ eczeństwo informacyjne w Polsce w 2019 r. Retrieved from https://stat.gov.pl/obszary-tematyczne/nauka-itechnika-spoleczenstwo-informacyjne/spoleczenstwo-informacyjne/spoleczenstwo-informacyjne-w-polsce-w-2019-roku,2,9.html (In Polish).

Historia czł onkostwa Polski w UE (2012). Retrieved from http://polskawue.gov.pl/Historia, czlonkostwa,Polski,w,UE,52.html. (In Polish)

Kocikowski, A. (2009). Raz jeszcze o tzw. "społeczeństwie informacyjnym", Społ eczeństwo Informacyjne. Wybrane zagadnienia i problemy, 16: 107-124. (In Polish).

Komorowska, Ewa \& Klimczak, Patrycja (2019). Strategia Lizbońska. Encyklopedia Zarzadzania. Retrieved from https:// mfiles.pl/pl/index.php/Strategia Lizbo\%C5\%84ska

Krztoń, W. (2015). XXI wiek - wiekiem społeczeństwa informacyjnego. Modern Management Review, vol. XX, 22 (3): 101-112. (In Polish)

Marciński, W. (2012). Integracja przez Internet. Retrieved from http://kaszpir.hlds.pl/mail...com.../Integracja\%20przez\%20Internet.doc.1 (In Polish).

Niesporek, A. (2018). Społ eczeństwo informacyjne w perspektywie socjologicznej, Retrieved from https://www.researchgate.net/publication/-328562781_Spoleczenstwo_informacyjne_w_perspektywie_socjologicznej (In Polish).

Nowak, M. (2010). Działania obywatelskie a transformacja ustrojowa w Polsce. Ruch Prawniczy, Ekonomiczny i Socjologiczny, 1: 169-188 (In Polish).

Pawłowska, A. (2005). Społ eczeństwo informacyjne, w: Encyklopedia wiedzy politycznej. Toruń; ss. 477. (In Polish)

Raport o Rozwoju Spot ecznym - Polska w drodze do globalnego społ eczeństwa informacyjnego (2001). Retrieved from http://unic.un.org.pl/nhdr/2001/index.php?rok. (In Polish)

Stachowiak, Beata (2008). Rozwój społ eczeństwa informacyjnego w krajach Unii Europejskiej a procesy globalizacyjne, Retrieved from https://www.researchgate.net/publication/2368- 
84483_Rozwoj_spoleczenstwa_informacyjnego_w_krajach_Unii_Europejskiej_a_procesy_globalizacyjne (In Polish).

Strategia Europa 2020 (2010). Retrieved from https://ec.europa.eu/eu2020/pdf/1_PL_ACT_part1_v1.pdf.

\section{LIST OF REFERENCE LINKS}

Cellary W. Streszczenie raportu o Rozwoju Społecznym Programu Narodów Zjednoczonych ds. Rozwoju. URL: https:// www.kti.ue.poznan.pl/specials/nhdr2002/index.htm (27.10.2012).

Demczuk A. Od raportu Bangemanna do Strategii Europa 2020. Rozwój społeczeństwa informacyjnego w polityce Unii Europejskiej - bilans 15 lat. Annales Universitatis Mariae CurieSkł odowska. 2016. vol. XXIII, 2 sectio k; ss. 25-44.

Dzeban O., Aleksandrova O., \& Vinnikova N. Axiological portrait of information society. Skhid. 2019. № 5(163). C. 13-19. DOI: http://dx.doi.org/10.21847/1728-9343.2019.5(163).18243

Filas R. Dwadzieścia lat przemian polskich mediów (19892009) w ujęciu periodycznym. Zeszyty Prasoznawcze. 2010. nr 34. ss. 27-54.

Golka M. Czym jest społeczeństwo informacyjne? Ruch Prawniczy, Ekonomiczny i Socjologiczny. 2005. zeszyt 4, ss. 253-265.

GUS, Społeczeństwo informacyjne w Polsce w 2019 r. URL https://stat.gov.pl/obszary-tematyczne/nauka-i-technika-spoleczenstwo-informacyjne/spoleczenstwo-informacyjne/spoleczenstwo-informacyjne-w-polsce-w-2019-roku,2,9.html (6.12.2019). Historia członkostwa Polski w UE. URL: http://polskawue.gov.pl/Historia,czlonkostwa,Polski,w,UE,52.html (27.10.2012).

Kocikowski A. Raz jeszcze o tzw. "społeczeństwie informa- cyjnym". Społ eczeństwo Informacyjne. Wybrane zagadnienia $i$ problemy. 2009. nr 16. ss. 107-124.

Komorowska Ewa, Klimczak Patrycja. Strategia Lizbońska. Encyklopedia Zarządzania. 2019. URL: https://mfiles.pl/pl/ index.php/Strategia Lizbo\%C5\%84ska (6.12.2019).

Krztoń W. XXI wiek - wiekiem społeczeństwa informacyjnego. Modern Management Review. MMR. 2015. vol. XX. 22 (3). ss. 101-112.

Marciński W. Integracja przez Internet, URL: http://kaszpir.hlds.pl/mail...com.../Integracja $\% 20$ przez $\% 20$ Internet.doc. 1 (27.10.2012).

Niesporek A. Społeczeństwo informacyjne w perspektywie socjologicznej. 2018. URL: https://www.researchgate.net/publication/328562781_Spoleczenstwo_informacyjne_w_perspektywie_socjologicznej (6.12.2019).

Nowak M. Działania obywatelskie a transformacja ustrojowa w Polsce. Ruch Prawniczy, Ekonomiczny i Socjologiczny. 2010. zeszyt 1. ss. 169-188.

Pawłowska A. Społeczeństwo informacyjne. Encyklopedia wiedzy politycznej / red. M. Chmaj, J. Marszał ek-Kawa, W. Sokół . Toruń, 2005. ss. 477

Raport o Rozwoju Społecznym - Polska w drodze do globalnego społeczeństwa informacyjnego. URL: http://unic.un.org.pl/ nhdr/2001/index.php?rok (6.12.2019).

Stachowiak Beata. Rozwój Społeczeństwa Informacyjnego w UE. URL: https://www.researchgate.net/publication/236884483-

_Rozwoj_spoleczenstwa_informacyjnego_w_krajach_Unii_Europejskiej_a_procesy_globalizacyjne (27.10.2012).

Strategia Europa 2020. URL: https://ec.europa.eu/eu2020/pdf/ 1_PL_ACT_part1_v1.pdf (6.12.2019).

Лукаш Донай,

Університет імені Адама Мічкевича у Познані (м. Познань, Польща)

e-mail: lukasz.donaj@amu.edu.pl,ORCID0000-0002-7720-1260

Віталій Завадський,

Київський університет імені Бориса Грінченка (м. Київ, Украӥна)

e-mail:v.zavadskyi@kubg.edu.ua,ORCID 0000-0002-0384-5979

\section{польСькИЙ шляХ ДО ІнФОРМАЦІЙНОГО сУСпІльСТВА}

Стаття присвячена розгляду широкого кола проблем, пов'язаних з соціокультурними змінами, що супроводжують перехід від індустріального до інформаційного суспільства. Метою статті є спроба показати польський шлях до інформаційної цивілізації. Для цього автор використовує такі методи, як історичний, поведінковий (непрямий) аналіз, метод прийняття рішень, а також екстраполяцію та рефлексію. В статті обговорюються проблеми коректності дефініцій понять, пов'язаних з інформаційним суспільством. Аналізується специфріка трансформації польського суспільства в контексті зовнішніх факторів, враховуючи європейську інтеграцію та, ширше - глобальні соціальні процеси. Простежено історичну динаміку розбудови інформаційної інфраструктури Польщі та показано, що цей шлях ще не завершений, аби можна було говорити, що інформаційна в Польщі настала остаточно.

Ключові слова: інформаційне суспільство; Польща; трансформації; Лісабонська стратегія; Європейська стратегія 2020.

(c) Lukasz Donaj, Vitaliy Zavadskyi

Надійшла до редакції: 20.01.2020

Прийнята до друку: 14.02.2020 